\title{
STUDI KARAKTER EKSTROVERT DAN INTROVERT SEBAGAI PENDUKUNG PERANCANGAN KARAKTER FILM ANIMASI PENDEK
}

\author{
Erika Krisanti \\ School of Design-Animation, Binus University \\ rika.e26@binus.ac.id
}

\begin{abstract}
Abstrak
Penelitian ini bertujuan untuk mengetahui karakteristik yang unik pada sifat ekstrovert dan introvert agar dapat merancang dan menghasilkan aset-aset visual yang berkaitan dengan karakter ekstrovert dan introvert. Peracangan karakter tersebut dijadikan sebagai konsep dasar untuk perancangan film animasi pendek. Pengumpulan data ekstrovert dan introvert ini menggunakan cara pengumpulan data kualitatif, yakni dengan cara melakukan wawancara dengan psikolog, wawancara dengan character designer, serta wawancara dan observasi terhadap 2 orang ekstrovert dan 2 orang introvert. Penambahan data juga dilakukan dengan studi kepustakaan. Hasil dari penelitian ini menunjukan bahwa ekstrovert memang memiliki sifat yang lebih terbuka, periang, ramah, dan banyak bicara namun terkadang sifat itu dapat mengganggu, sedangkan introvert memiliki sifat yang umumnya penyendiri dan pendiam yang membuat mereka terlihat cuek dan sombong. Namun dengan adanya perbedaan karakteristik ini menjadikan mereka teman yang saling melengkapi. Kemudian data tersebut digunakan sebagai data visual seperti bentuk tubuh, model rambut, dan referensi warna. Hasil dari penelitian ini menghasilkan tiga karakter utama yaitu Sarah, Bill, dan Paul. Sarah adalah karakter wanita ekstrovert yang memiliki rambut mekar, bentuk tubuh berbentuk jam pasir, dan warna yang mencolok. Bill adalah karakter pria ekstrovert yang memiliki rambut mekar namun rapih, tinggi, bentuk tubuh segitiga, dan warna terang. Paul adalah karakter pria introvert, memiliki rambut yang biasa, jangkung dan ramping serta bentuk tubuh kotak.
\end{abstract}

Kata Kunci: Studi Karakter, Ekstrovert dan Introvert, Perancangan Karakter

\begin{abstract}
The goal of research was to know the uniqness of extrovert and introvert characteristics in order to design and creating the visual assets that associated with extrovert and introvert character. The character design will be used as the base concept for short animation film design. This extroverted and introverted data was collected using qualitative data collection method, by interviewing with psychologist, interviewing character designer, also interviewing and observation with 2 extroverts and 2 introverts people. The addition of data is also done by literature study. The result of this thesis was showing that extroverts do more open, cheerful, friendly and talkative but sometimes it could be annoying, while introvert mostly tend to be loner and quiet which makes them looks ignorant and arrogant. However with these different characteristic makes them a complementary friends. Then the data is translated into a visual data such as body shapes, hairstyle, and color references. The result of this research produced the three main characters named Sarah, Bill, and Paul. Sarah is an extroverted female character who has a blooming hair, an hourglass body shape, and bright colors. Bill is an extroverted male character who has blooming hair but neat, tall, triangle body shape, and light colors. Paul is an introverted male character, has standard hair, tall and slender also a square body shape.
\end{abstract}

Keywords: Character Research, Extrovert and Introvert, Character Design 


\section{PENDAHULUAN}

Film animasi pasti memiliki tujuan lain selain menghibur, seperti memberi wawasan kepada masyarakat. Umumnya di Indonesia, film animasi 3D yang ditayangkan dan diproduksi bertema tentang petualangan dan kehidupan sehari-hari yang biasanya disajikan untuk anak-anak. Walau animasi identik dengan film anak-anak, masih banyak remaja dan dewasa yang suka dengan animasi buatan Pixar, Dreamworks, Illumination dan lainnya. Tema film yang diambil oleh perusahaan besar itu cukup luas dan dapat dinikmati semua orang.

Inside Out merupakan salah satu film animasi 3D karya Pixar yang sempat meledak pada tahun 2015 lalu. Film tersebut cukup membuka wawasan banyak orang mengenai emosi apa saja yang mengontrol di kepala seseorang untuk bertindak. Lalu penulis juga menyadari bahwa yang dapat mengontrol seseorang selain emosi adalah kepribadian yang benar-benar berasal dari dalam diri seseorang.

Setiap individu pasti memiliki cara berpikir, berbicara dan bertindak masingmasing. Hal tersebut yang mem-buat manusia mempunyai kepribadian yang unik dan berbeda dengan orang lain dan untuk memahami tiap individu adalah sebuah hal yang rumit, karena suatu kebiasaan yang membentuk se-seorang itu timbul dari kebudayaan dan lingkungan yang membentuk karakter seseorang. Akan tetapi, semua kepribadian tersebut dapat digolongkan menjadi beberapa jenis. Pada umumnya, kepribadian tersebut dibagi menjadi ekstrovert dan introvert.

Berdasarkan data yang telah diperoleh di dalam kaitannya dengan bidang studi Desain Komunikasi Visual, maka lingkup yang dibahas dibatasi pada hal-hal yang dapat ditangani atau diselesaikan melalui pendekatan DKV, yaitu dengan membuat komunikasi audio visual mengenai cerita pendek animasi yang dibuat dengan metode animasi 3D, tanpa dialog dengan tema cerita mengenai sifat-sifat ekstrovert dan introvert. Menceritakan tentang seorang wanita ekstrovert yang menjalin hubungannya dengan pria ekstrovert namun seiring dengan berjalannya waktu hubungan mereka tidak berjalan dengan baik, dan semua berbeda saat wanita ekstrovert itu bertemu dengan pria introvert.

Ekstrovert dan introvert memiliki ciri-ciri unik yang menarik untuk dipahami. Oleh karena itu, hal tersebut menarik penulis untuk memahami dan mencari tau lebih lagi bagaimana memvisualisasikan atau mendesain karakter ekstrovert introvert menjadi karakterkarakter dalam animasi yang menarik. Sehingga karakter tersebut bisa mewakili kepribadian ekstrovert atau introvert dan cerita yang disampaikan dari animasi pendek tersebut dapat berkesan. Tujuan dari animasi pendek ini adalah memberikan sebuah informasi bahwa karakter tiap orang berbeda dan ada dua jenis karakter yang disebut ekstrovert dan introvert, mereka berbeda namun perbedaan tersebut yang membuat mereka saling membutuhkan.

\section{Kajian Literatur}

Perancangan Karakter

Desain karakter dalam sebuah cerita memegang peranan penting. Film, game, dan juga komik selalu menonjolkan karakter yang ada di dalam cerita tersebut dan dibuat semenarik mungkin agar audience tertarik.

Ada 20 cara membuat character design dari Jon Burgerman

(Creativebloq, 2015), yaitu:

1. Decide who it's aimed at

2. Decide where it will appear

3. Research other designs

4. Make your character distinctive 
5. Use line qualitues and styles to describe your character

6. Use exaggerated characteristics

7. Choose colours carefully

8. Add accessories

9. $2 D$ or $3 D$

10. Give your character personality

11. Focus on facial expression

12. Give your character goals and dreams

13. Build up a back story

14. Experiment

15. Make your character design flexible

16. Swap mouse for pen

17. Get feedback from others

18. Hone, plan and polish your design

19. Create the right environtment for your character

20. Fine-tune your figure

Bentuk dalam Karakter

Bentuk dapat membantu dalam sebuah perancangan karakter menurut Tillman, (Creative Character Design, 2011) :

1. Square

Umumnya saat melihat sebuah bentuk kotak, istilah yang seharusnya muncul adalah Stability, Trust, Honesty, Order, Conformity, Security, Equality, Masculinity.

Hal tersebut adalah hal terumum yang biasanya dipikiran oleh seseorang jika melihat bentuk kotak. Penting untuk mengetahui informasi seperti ini saat membuat karakter karena kita tidak ingin memberikan arti yang tidak benar.

2. Triangle

Bentuk Segitiga menyampaikan istilah Action, Aggression, Energy, Sneakiness, Conflict, Tension.

3. Round

Lingkaran dapat dilihat sebagai Completeness, Gracefulness, Playfulness, Comforting, Unity, Protection, Childlike.
Bentuk tidak hanya berperan dalam bentuk wajah karakter namun berguna untuk bentuk tubuh juga.

\section{Ekspresi dalam Karakter}

Mata dan wajah ada kunci utama dari sebuah ekpresi. Dalam buku The Illusion of Life (1981) dijelaskan bahwa, mata adalah bagian terpenting dalam ekspresi dan harus digambar dengan ekstra hati-hati. Sedikit gerakan tak beraturan atau gerakan yang salah diantaranya menghancurkan baik komunikasi dan kepercayaannya. Seperti yang dikatakan Walt, penonton melihat matanya, dan inilah dimana waktu dan uang harus dihabiskan jika karakternya diminta untuk bertingkah meyakinkan. Disney telah menemukan bertahun-tahun bahwa hubungan tertentu membuat ekspresi terbaca. Tidak ada bagian dari ekspresi, baik mata, atau bagian tersendiri lainnya dapat berkomunikasi jika sebuah ekspresi tidak bekerja sama. Untuk mendapatkan kesatuan ini, harus ada hubungan dekat antara bagian-bagian penting ini. Jika jarak dari fitur-fiturnya terlalu berjauhan maka akan susah untuk membacanya dan menyulitkan bagian lain untuk berinteraksi dengan yang lain. Ini tentu saja, karena pengalaman terbesar kita dengan ekspresi adalah dengan wajah manusia. Jika garis mulut mempunyai hubungan dekat dengan mata, mulut dapat menekan pipi ke kelopak mata bagian bawah saat tersenyum, dengan demikian menghubungkan semua kunci pada bagian wajah.

Akting sebagai Pendukung Gerakan

Cara membuat karakter "berakting” menurut Tom Bancroft (2012), yakni:

1. Acting

Ingat, jika karakter anda adalah "aktor," maka Anda adalah "direktur"nya. Karakter Anda akan menceritakan cerita yang anda 
berikan - sesuai dengan cara yang anda inginkan.

2. Subtext

"Subtext" adalah istilah yang dapat menambah kedalaman acting pada karakter Anda. Subtext dari penampilan karakter adalah pemikiran dalam mengenai pikiran atau perasaan dari kalimat yang mereka ucap.

3. Purpose-Driven Acting

Sebagai seorang direktur dari karakter Anda, pikirkan tentang apa yang memotivasi mereka untuk melakukan/berkata/rasakan apa yang seharusnya mereka lakukan pada saat itu. Jika anda tidak memikirkan hal tersebut, audience tidak akan mengerti arti dari gambar/adegan/ilustrasi/aksi.

4. Eye Direction and Proximity

Membuat karakter yang baik, pose yang kuat dan menarik adalah hal penting, tetapi jika karakter Anda terlihat tidak berinteraksi dengan karakter lain, Anda menghilangkan kunci utama dari sebuah storytelling. Arah pandangan mata adalah kunci utama untuk mengilustrasikan interaksi dari karakter.

Proximity adalah isitilah yang Bancroft pakai sebagai acuan untuk seberapa dekat sebuah obyek (atau properti, istilah panggung) atau orang itu kepada karakter yang ber-akting dengan properti atau orang itu. Apa perasaan dan emosi mereka berada dalam proximity yang benar? Proximity dari karakter Anda bekerja sama dengan arah pandang mata, karena seberapa dekatnya karakter dan seberapa mereka memandang mata satu sama lain menceritakan chemistry antara mereka.

5. Using Photo Reference

Ketika Bancroft sedang melihat referensi foto, ia menanyakan pertanyaan ini: a. Apa yang paling menarik dari pose ini?

b. Apa yang dapat di tingkatkan?

c. Perubahan apa yang perlu dilakukan agar karakternya dapat masuk ke pose tersebut?

6. Characters Listening to Each Other

Hal ini sangat tergantung pada apa yang dikatakan oleh karakter lain dalam konteks cerita. Dan poin utamanya disini: jangan pernah lupa apa yang seharusnya karaker pikirkan tentang apa yang dikatakan pada nya. Semua berkaitan dengan bagaimana cara ia mendengarkan dan bereaksi.

\section{Introverted Vs. Extraverted}

Ekstrovert berarti mengarahkan energi psikis ke luar dan berorientasi kepada objek dan jauh dari subjektif. Seorang dengan kepribadian ekstrovert lebih dipengaruhi oleh sekeliling mereka daripada dunia dalam diri mereka. Sedangkan introvert berarti mengalihkan energi psikis ke dalam diri yang bersifat subyektif dalam memandang dunia. Seorang dengan kepribadian introvert hidup di dunia dalam diri mereka sendiri bersama dengan bias, khayalan, mimpi, dan persepsi individual mereka. Mereka juga menerima dan mempersepsi dunia eksternal, tetapi mereka melakukannya secara selektif dan dengan pandangan subjektif mereka (Jung dalam Feist \& Feist, 2006).

Menurut Laney \& Laney (2007) Introvert memiliki kecenderungan :

1. Mereka berpikir sebelum bertindak atau berbicara.

2. Mereka melakukan kontak mata ketika mendengarkan, sedikit ketika berbicara.

3. Ketika berbicara mereka memiliki suara lembut, terlihat tenang, sering terhenti, terdengar ragu, dan mencari kata-kata. 
4. Mereka menikmati kesendirian dan merasa "kering" setelah terlalu lama bersosialisasi.

5. Mereka lebih memilih berbicara satu lawan satu kepada party patter (obrolan kosong).

6. Mereka memiliki satu atau dua teman baik.

Sedangkan Ekstrovert memiliki kecenderungan :

1. Mereka berbicara serampangan.

2. Mereka bertindak duluan dan dipikirkan kemudian.

3. Mereka melakukan kontak mata ketika berbicara, sedikit ketika mendengarkan.

4. Ketika berbicara mereka menunjukan ekspresi wajah, menggerakan tubuh muereka, memotong orang lain, berbicara kencang, terdengar otoriter dan silver tongue (mampu secara jelas dan efektif mengekspresikan diri).

5. Mereka menikmati kesenangan, kegiatan yang banyak, dan bersosialisasi serta merasa "kering" jika terlalu lama sendiri.

6. Mereka menganggap banyak orang untuk dijadikan teman mereka.

7. Mereka menyukai party chatter (orang yang banyak bicara).

Dari hasil penelitian 16 Personalities (2016) membuktikan bahwa Introvert lebih sering diberitakan lebih sensitif terhadap suara dan warna cerah, mereka juga lebih memilih kesederhaan dan minimalisme dalam lingkungan mereka (khususnya jika Introversion terkait dengan Thinking trait). Mereka juga tidak mencari atau membutuhkan stimulasi dari luar - ketika sedang berkomunikasi dengan orang lain adalah contoh stimulasi paling jelas, konsep ini juga meluas ke hal lain seperti hobi, pandangan politik dan bahkan kebiasaan makan atau minum. Contohnya, Introvert biasanya tidak menyukai kopi dan minuman berenergi. Sedangkan pada spektrum yang berlawanan, Ekstravert lebih tertarik untuk terlibat di dalam lingkungan -orang dan benda di sekitar mereka- dan mereka membutuhkan masukan juga. Mereka lebih berenergi dan rela memimpin di banyak situasi, khususnya pada kegiatan sosial, dan mereka suka mendorong batas dan menantang baik diri mereka dan orang di sekitarnya. Orang yang memiliki kepribadian Ekstravert biasanya lebih sering merasakan bahwa mereka dapat mengatasi segala rintangan yang ada di jalan. Lebih jelasnya, antara benar atau tidak hal tersebut tergantung dari berbagai keadaan, tetapi secara umum Ekstravert lebih proaktif dalam pengalaman (dan untuk diandalkan) di dunia sekitar mereka.

Menurut Luscher (1971), Studi tentang efek warna pada kegembiraan menunjukkan bahwa ada korelasi antara preferensi warna dan ciri kepribadian. Lebih tepatnya, para introvert lebih menyukai warna "tenang" (seperti biru), karena mengurangi kegembiraan, sedangkan eksrovert lebih menyukai warna "menarik" (seperti merah), karena meningkatkan tingkat kegembiraan

\section{Perancangan Cerita}

Beberapa elemen utama yang penting untuk sebuah cerita (Ideas for The Animated, 2013), yaitu:

1. Character. Mengenai siapa karakter itu dan melalui sudut pandang siapa cerita ini diceritakan.

2. Goal. Objek fisik yang ingin didapatkan oleh karakter utama : sang puteri, harta karun, seorang gadis, hadiah, pengakuan, harga diri, dan sebagainya.

3. Conflict. Konflik adalah apa yang menghalangi si karakter dan tujuannya. Ada tiga bentuk konflik:
a. Character vs. Character
b. Character vs. Environment
c. Character vs. Self 
Konflik membuat masalah, rintangan dan dilema yang menempatkan karakter dalam sebuah bahaya, baik secara fisik, mental, atau rohani. Ini artinya akan ada sesuatu yang dipertaruhkan jika karakter tidak mengatasi konflik.

Kemudian elemen lainnya dalam cerita meliputi:

1. Location. Ini adalah tempat, atau atmosfer yang mendukung cerita tersebut.

2. Inciting Moment. Dalam setiap cerita, dunia dari karakter berjalan seperti biasa hingga sesuatu yang tidak disangka terjadi dan memulai cerita.

3. Story Question. Inciting moment memunculkan pertanyaan dalam benak orang yang menonton, yang harus dijawab diakhir cerita.

4. Theme. Tema adalah sebuah pelajaran hidup. Cerita memiliki makna. Tema adalah arti mendalam dari disampaikan cerita. Tema yang umum adalah jujur kepada diri sndiri, jangna meninggalkan teman di belakang, manusia melawan alam, dan cinta mengalahkan segalanya.

5. Need. Dalam sebuah cerita akan ada apa yang ingin dicapai karakter atau tujuannya. Kemudian apa yang karakter butuh pelajari atau temukan untuk mencapai tujuannya.

6. Arc. Saat karakter mempelajari bahwa akan ada yang disebut emotional arc atau perubahan dalam karakter dalam perpindahan dari hal apa yang ia mau ke hal yang ia butuhkan.

7. Ending/ Resolution. Bagian akhir adalah apa yang harus diberikan kepada penonton untuk menimbulkan kelegaan emosional dan menjawab semua pertanyaan yang ada di cerita. Ending harus dapat merubah penonton atau karakter dalam cerita.

\section{Data Wawancara}

Melalui kegiatan wawancara ini, peneliti berupaya mendapakatan informasi umum mengenai karakter ekstrovert dan introvert melalui seorang ahli mengenai kepribadian yaitu psikolog yang bernama Ibu Rani Agias Fitri, M. Psi., Psikolog (37). Beliau adalah dosen psikolog di Universitas Bina Nusantara, Kampus Kijang. Berdasarkan hasil wawancara dengan Ibu Rani, didapatkan beberapa kesimpulan, bahwa:

1. Ekstrovert dan introvert sebenarnya bagian dari trait yang dimiliki oleh manusia, jadi sebenarnya seseorang itu hanya ditemukan satu trait yaitu extravertion, tetapi extravertion itu memiliki ada tinggi dan rendah ketika dia tinggi itu disebut extravertion tetapi ketika rendah itu disebut introvertion.

2. Hal ini juga dapat ditemukan dari lahir karena yang mempengaruhi adalah faktor genetik yang diturunkan dari orangtuanya namun akan terlihat saat ia mulai bisa bersolialisasi. Introvert dan ekstrovert tidak selalu bisa ditebak dari luar namun akan semakin kelihatan ketika diajak berbicara.

3. Perbedaan paling mencolok antara ekstrovert dan introvert adalah kemampuan bersosialisasinya. Ekstrovert memiliki emosi yang positif, itulah yang menjadi kelebihannya. Kekurangannya, untuk tugas yang dikerjakan sendiri ia lebih susah untuk memikirkan atau merenungnya sendiri namun hal ini menjadi kelebihan introvert. Kekurangannya introvert itu, mereka kadang terlalu sensitif karena terlalu banyak pikiran. Secara umum, ekstrovert akan menyukai warnawarna cerah, kalau introvert ke warna yang tenang.

4. Gesture pada ekstrovert dan Introvert berbeda karena ada perbedaan energi 
dan pengaruh neurologi, bahwa ekstrovert itu justru berenergi kalau berinteraksi dengan orang lain, sedangkan introvert tidak banyak energi dalam dirinya jadi tidak diperlukan stimulus dari luar, dia sudah cukup dengan dirinya sendiri. Karakter yang berbeda itu menjadikan mereka saling melengkapi terutama untuk percintaan. Terkadang ekstrovert membutuhkan introvert untuk mendengarkan celotehannya.

Selanjutnya peneliti melakukan wawancara kepada orang-oarng ekstrovert dan introvert yang berjumlah 4 orang, di antaranya:

1. Mimi (25), seorang ekstrovert yang berprofesi sebagai seorang public figure.

2. Alfred Colin (22), seorang ekstrovert yang berprofesi sebagai Business Development Assistant.

3. Tabhita Mutiara (23), seorang introvert yang bekerja freelance biasanya pada bagian event organizer.

4. Mikael Louis (20), seorang introvert, yang merupakan mahasiswa.

Untuk mempersingkat dan memperjelas hasil wawancara yang dilakukan maka peneliti akan menyimpulkan jawaban secara keseluruhan menurut pertanyaan:

1. Ekstrovert adalah orang yang terbuka dan mudah bergaul, sedangkan introvert adalah orang yang pasif dalam bergaul.

2. Kelebihan ekstrovert banyak teman karena mudah bergaul, kekurangannya terlalu banyak bicara. Sedangkan kelebihan introvert diam dan tenang, kekurangannya dianggap cuek.

3. Cara membedakan seseorang ekstrovert dan introvert adalah melalui bersosialisasi, ekstrovert akan lebih aktif, introvert akan cenderung lebih pasif.
4. Ekstrovert lebih memiliki teman yang introvert begitu juga sebaliknya.

5. Menurut temannya, ekstrovert adalah orang yang gila, sedangkan untuk introvert lebih tergantung kepada individu itu sendiri.

6. Ekstrovert wanita memilih baju yang berwarna-warni, ekstrovert pria memilih baju berwarna seperti merah dan biru. Introvert cenderung memilih baju berwarna netral atau gelap.

7. Kegiatan yang ekstrovert bersemangat adalah jalan-jalan dan makan. Sedangkan introvert tergantung preferensi masing-masing, ada yang suka jalan-jaln dan makan juga, ada yang lebih suka berkumpul dengan teman dan ngobrol.

8. Kondisi kamar menurut responden ekstrovert lebih rapih dibandingkan introvert yang lebih berantakan.

9. Untuk menyelesaikan sebuah konflik, ekstrovert cenderung menyelesaikan masalah dengan face to face, sedangkan introvert tergantung dengan masing-masing individu, bisa face to face atau melalui chat.

10. Hal yang ditakuti oleh kedua ekstrovert tersebut adalah dikhianati oleh teman. Introvert wanita takut akan prasangka buruk orang lain, sedangkan introvert pria takut akan kekalahan.

Selanjutnya, peneliti mencari saran mengenai cara membuat karakter melalui seorang ahli character designer yang bernama Mutia Intani Terian (32). Beliau merupakan lulusan dari Academy of Art University, San Francisco dan profesinya sekarang adalah sebagai Art Director di Maxx Animation dan sebagai Lecturer. Berdasarkan hasil wawancara, peneliti menyimpulkan bahwa hal penting untuk membuat sebuah desain karakter adalah mengenal baik serta dalam mengenai karakter yang akan dibuat. Lalu menentukan bentuk yang sesuai dengan 
karakter agar siluet-nya dapat dikenal orang. Terakhir adalah gesture atau sikap, gerak-gerik dari karakter tersebut. Baju dan atribut lainnya hanya menambah kejelasan karakter, warna juga dapat digunakan sebagai elemen pendukung dalam karakter ekstrovert introvert. Dimana ekstrovert introvert dapat dilihat dalam karakter Joy dan Sadness dari film animasi Inside Out karya Pixar.

\section{Data Observasi}

Peneliti melakukan observasi sembari wawancara berlangsung dengan narasumber ekstrovert dan introvert. Berikut adalah hasil observasi yang penulis dapat jelaskan:

1. Reaksi saat berkenalan dengan orang baru

a. Ekstrovert memperkenalkan diri duluan, memberi salam dan bersuara lebih lantang, ditambah senyuman lebar, serta terlihat tidak canggung.

b. Introvert menerima salam dengan menyebutkan nama dan senyum seadanya.

2. Gesture saat berbicara

a. Ekstrovert memulai obrolan duluan, tidak canggung, lebih bercerita banyak (ekstro:intro = 3:1), saat wawancara berlangsung Mimi (ekstrovert 1) sering menyambungi jawaban orang lain, seperti dari Alfred (ekstrovert 2). Saat berbicara ekstrovert melakukan eye contact, serta banyak gerakan tangan, kepala, sehingga terlihat mereka bercerita dengan semangat. Ekstrovert sangat ekspresif dalam berbicara, dan dapat meyakinkan pembicaraan dengan sangat baik.

b. Introvert cenderung mendengarkan saja dan sesekali menjawab, saat wawancara berlangsung introvert hanya menjawab seadanya sesuai pertanyaan, Tabhita (introvert 1) lebih bisa menjelaskan jawaban lebih baik, sedangkan Mikael (introvert 2) berpikir cukup lama untuk satu pertanyaan dan memberi contoh untuk mengungkapkan jawabannya, eye contact tidak begitu sering pada saat mereka berbicara. Untuk ekspresi, Tabhita (introvert 1) lebih netral dan sesekali tersenyum, Mikael (introvert 2) terkadang senyum dan tertawa.

3. Pakaian

a. Ekstrovert dan Introvert samasama memiliki casual style, Mimi (ekstrovert 1) menggunakan baju dan rok hitam 1 set yang memiliki corak-corak abstrak berwarna nyentrik dan sepatu, Alfred (ekstrovert 2) memakai baju turtle neck merah dan jaket hitam, celana jeans panjang dan sepatu. Tabhita (introvert 1) menggunakan baju hitam, celana hitam dan sepatu, Mikael (introvert 2) menggunakan baju lengan sampai siku berwarna abu gelap dengan celana gelap bercorak dengan sandal slip on.

b. Pada saat pertemuan pertama dengan Mimi (ekstrovert 1) memang paling mencolok dari yang lain dikarenakan ia mengisi sebuah acara, namun pada pertemuan kedua, yang tujuannya hanya untuk jalan-jalan. Baju yang dikenakan sangat mencolok terdapat warna merah, biru, kuning mencolok pada baju berdasar putih dan celana pendek merah, sedangkan Alfred (ekstrovert 2) tetap cenderung memakai warna yang biasa.

\section{Existing Study}

Berikut adalah tinjauan dari beberapa cerita dan karakter yang dipelajari oleh peneliti: 
1. Studi cerita In/Ex Troversion

Animasi 2d karya Julia Gomes

Rodrigues tersebut bercerita tentang setiap orang memiliki baterai sebagai indikator ekstrovert atau introvert yang akan terisi atau habis jika melakukan sebuah kegiatan. Seorang wanita introvert diajak kesebuah pesta yang membuat baterainya cepat habis karena banyak orang yang tidak dikenal, terlalu ramai yang membuatnya tidak nyaman. Sedangkan orang lain yang asik minum, menari dan bersenang-senang terus bertambah karena mereka adalah seorang ekstrovert. Setelah suasana makin tidak nyaman yang membuat karakter introvert tersebut panik akhirnya ia memutuskan untuk pulang.

2. Studi cerita Histoire 2 Couples

Animasi pendek karya William Loew, Davy Crosta, Alcindo Da Conceicao, Adrien Cuvit, AnneCharlotte Benasouli, dan Camille Burdy yang menceritakan tentang seorang pria muda yang energik jatuh cinta kepada wanita yang kecanduan dengan telpon genggamnya. Dari semua kegiatan yang mereka lalui, wanita itu hanya terus melihat telponnya dan membuat pria itu sedih dan jenuh dengan hubungannya hingga suatu saat ia bertemu dengan wanita muda yang juga jenuh dengan hubungannya dengan pria yang hanya sibuk main bola pingpong.

3. Studi Cerita Inside Out

Animasi karya Pixar ini menceritakan bahwa manusia dikontrol oleh 5 emosi utama yang ada berada didalam otak, yaitu Joy (senang), Sadness (sedih), Disgust (jijik), Fear (takut), dan Anger (marah). Dalam cerita tersebut, Joy dan Sadness adalah kedua karakter yang memiliki konflik, dimana Joy tidak suka dengan Sadness karena selalu merusak memori bahagia menjadi sedih, namun sesungguhnya kejadian bahagia itu ada karena adanya kesedihan.

Dari ketiga animasi diatas, memiliki persamaan dimana animasi tersebut membuat pertemuan antara karakter yang sifatnya sangat berbeda dengan karakter lain sehingga menimbulkan. Namun solusi yang ditawarkan menjadi akhir cerita cukup berbeda, pada animasi pertama setelah bergumul dengan diri sendiri akhirnya karakter memutuskan untuk keluar dari zona tidak nyaman tersebut, cerita kedua memasangkan karakter utama ke karakter lain yang memiliki konflik yang sama, cerita ketiga membuat kedua perbedaan karakter tersebut menjadi karakter yang saling melengkapi.

4. Studi Warna

Sebuah jurnal berjudul "Personality Traits and Colour Preferences" yang ditulis oleh Vojislava Bugarski dan Dunja Cigić menghasilkan kesimpulan dari uji coba yang mereka lakukan, yaitu dengan mengintegrasikan hasil analisis diskriminan, dua tipe kepribadian yang beragam dapat dirumuskan. Tipe-1 mencakup individu yang lebih memilih warna gelap dan memiliki nilai tinggi pada dimensi neurotisme, namun rendah pada reliabilitas, aktivitas dan agresi. Subyek ini dapat digambarkan sebagai cenderungan untuk penarikan, kepasifan, ketegangan dan ketidakstabilan emosional. Orangorang ini lebih pendiam dan kurang agresif dibanding tipe-2 kepribadian. Tipe-2 mencakup orang-orang yang lebih memilih warna hangat dan aktif dan memiliki nilai tinggi pada dimensi Aktivitas, Agresi dan Keteguhan namun rendah pada dimensi Neurotisme. Orang-orang ini dapat digambarkan sebagai orang- 
orang yang cenderung mengambil inisiatif, memiliki pendekatan aktif, dan menunjukkan peningkatan agresivitas. Mereka secara emosional lebih stabil dan lebih mudah bergaul daripada tipe- 1 orang.

Hasil yang ditafsirkan dengan cara ini dapat mendukung pendapat bahwa orang memilih warna yang mereka suka sesuai dengan ciri kepribadian mereka, dan ciri kepribadian mereka menyerupai warna yang mereka sukai. Oleh karena itu, individu aktif memilih warna aktif, jelas, kuat (merah, kuning), sedangkan orang yang introvert dan cemas memilih warna gelap, berat, statis (coklat, abu-abu, hitam).

5. Studi Karakter

Dalam studi bentuk penulis menganalisa bentuk-bentuk serta atribut pada karakter untuk ekstrovert dan introvert yang berada dalam animasi Extinguished, On The Same Page, dan Jinxy Jenkins \& Lucky Lou.

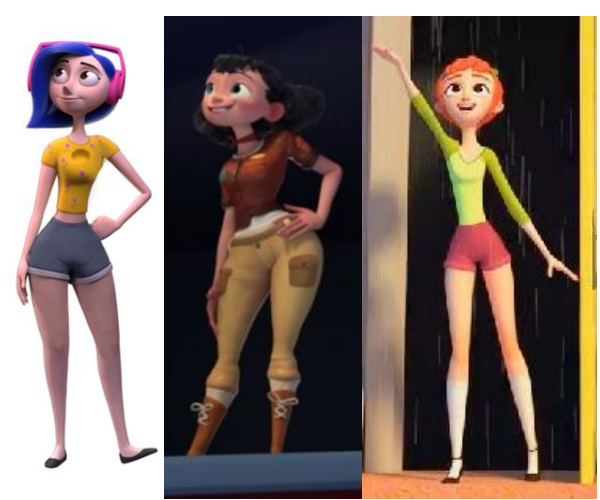

Gambar 2.2.1. Karakter Wanita

Persamaan dari ketiga karakter wanita tersebut memiliki bentuk kepala yang bulat, badan curvy atau hourglass menunjukan bentuk karakter yang feminim. Warna yang digunakan cenderung mencolok dan terang yang dapat menunjukan sebagai seseorang yang selalu bersemangat cocok untuk karakter ekstrovert.

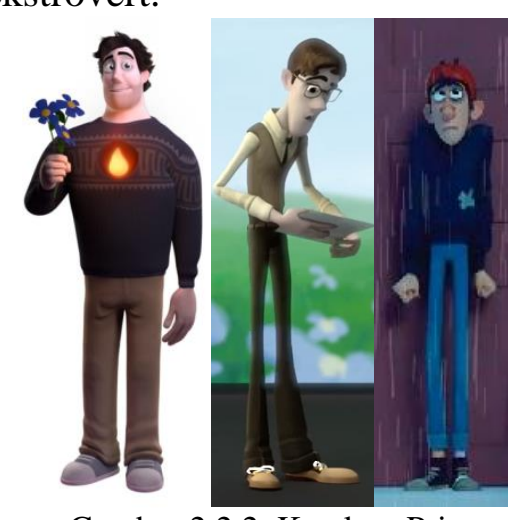

Gambar 2.2.2. Karakter Pria

Persamaan Ketiga karakter tersebut adalah menggunakan warna netral yang tidak mencolok dan dapat menunjukan karakter yang lebih tenang, bentuk wajah lebih panjang dari karakter wanita. Karakter pertama memiliki bentuk tubuh yang lebih kearah segitiga dibandingkan karakter kedua dan ketiga memiliki bentuk tubuh yang cenderung kotak, jangkung dan ramping, membuat karakter tersebut terlihat lemah dan tidak seberenergi karakter pertama.

\section{METODE PENELITIAN DAN PERANCANGAN}

Dalam penelitian ini pendekatan yang dilakukan adalah melalui pendekatan kualitatif. Data tersebut dapat berasal dari wawancara, catatan lapangan atau observasi yang tidak bergantung pada hasil atau jumlah angka-angka. Penulis menggunakan metode ini karena yang diteliti nantinya berupa hasil pengamatan, wawancara dan ucapan dari individu maupun kelompok yang dijadikan sebagai acuan dalam memvisualisasikan karakter tersebut.

Bodgan dan Biklen menjelaskan bahwa penelitian kualitatif adalah salah satu prosedur penelitian yang menghasilkan data deskriptif berupa ucapan atau tulisan dan perilaku orang- 
orang yang diamati. Pendekatan kualitatif diharapkan mampu menghasilkan uraian yang mendalam tentang ucapan, tulisan, dan atau perilaku yang dapat diamati dari suatu individu, kelompok, masyarakat, dan atau organisasi tertentu dalam suatu setting konteks tertentu yang dikaji dari sudat pandang yang utuh, komprehensif dan holistik.

Untuk memperoleh data dalam penelitian ini, langkah-langkah pengumpulan data yang dilakukan meliputi: wawancara, observasi, dan kepustakaan.

\section{Teknik Pengumpulan Data}

Menurut Sugiyono (2014) bila dilihat dari segi cara atau teknik pengumpulan data, maka tekni pengumpulan data dapat dilakukan dengan observasi (pengamatan), interview (wawancara), kuesioner (angket), dokumentasi dan gabungan keempat.

1. Teknik Wawancara

Untuk dapat memahami sebuah penjelasan lebih baik, maka teknik ini dilakukan untuk memperoleh data dari narasumber secara langsung. Pembahasan mengenai hal kepribadian maka akan dilakukan dengan mewawancarai seorang psikolog dan orang-orang yang ekstrovert atau introvert. Dalam wawancara tersebut penulis akan menggali informasi mengenai bagaimana perbedaan sifatsifat yang ada pada ekstrovert dan introvert. Sedangkan untuk narasumber yang berkaitan dengan skill, penulis akan mewawancarai seseorang yang sering mendesain sebuah karakter, yaitu seorang concept artist, komikus, atau character design artist mengenai cara memvisualisasi atau membuat sebuah karakter berdasarkan karakter ekstrovert dan introvert.

2. Teknik Observasi

Observasi dilakukan untuk mendapatkan data mengenai tingkah

laku atau ekspresi para ekstrovert atau introvert dengan cara mengamati perilaku mereka di tempat umum baik secara individu maupun kelompok.

3. Teknik Kepustakaan

Tahap ini dilakukan dengan cara mengkaji informasi yang bersumber seperti buku, jurnal, artikel atau majalah dan internet mengenai hal yang di teliti.

\section{HASIL DAN PEMBAHASAN}

\section{Desain Judul}

Untuk desain judul terdapat tiga alternatif judul, yaitu "Matched!" yang berarti cocok, dimana jika ada dua pasang orang saling menyukai profil dalam dating app (sebuah aplikasi kencan online) akan menandakan bahwa kedua pasangan tersebut cocok. "Apparié" yang merupakan bahasa Prancis dari kata matched atau paired. "Extraloversion" berasal dari kata extraversion lalu ditambah kata "lo" menambahkan kesan extra love yang artinya cinta ekstra. Serta enam jenis font, yaitu Lemon Tuesday, April Flower, Kisah Ceritra, Autumn Moon, Chewed Pen BB, dan Charlatan DEMO. Warna yang dipakai akan disesuaikan dengan warna background, namun penulis akan menggunakan warna putih sebagai warna utama.

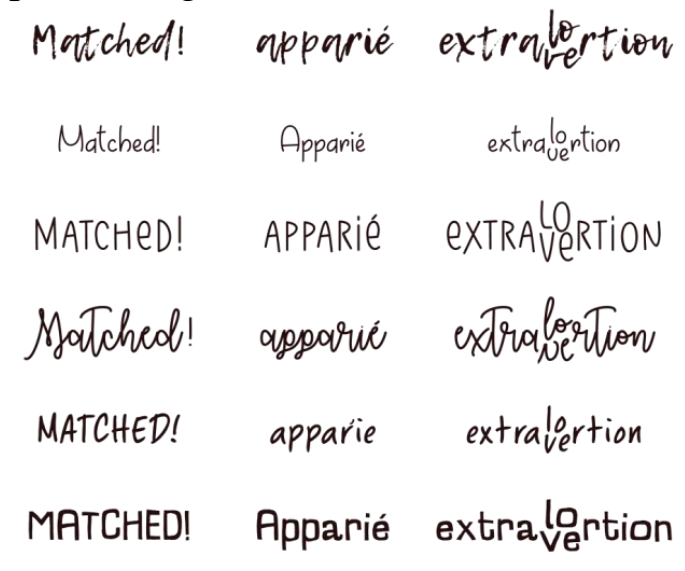

Gambar 2.4.1. Alternatif Judul 


\section{Desain Karakter}

Karakter menjadi peranan penting dalam animasi ini karena mereka yang akan menjadi pemeran karakter ekstrovert dan introvert. Berikut penjelasan dan pembahasan desain karakter.

\section{Karakter Ekstrovert}

Seorang ekstrovert akan selalu digambarkan sebagai seseorang yang sangat periang dan aktif baik saat berbicara maupun gerakan, karena energi yang mereka dapatkan berasal dari luar. Untuk menggambarkan hal tersebut, penulis membuat dua karakter ekstrovert yaitu Sarah dan Bill. Mereka dibuat dengan rambut yang cukup mekar serta bentuk badan yang atletis, untuk pria seperti segitiga terbalik untuk wanita berbentuk hourglass atau jam pasir.

Pemilihan warna yang digunakan adalah warna yang terang dan cerah. Karakter Sarah menggunakan warna seperti oren untuk rambut, mata coklat muda kekuningan atau hazel, pakaian dengan kombinasi warna hijau, kuning, putih, biru dan merah. Untuk karakter Bill menggunakan warna yang lebih normal tapi masih tergolong terang, rambut pirang, mata biru, pakaian dengan kombinasi merah, biru, cokelat, hitam, putih.

Sarah mempunyai paras yang cantik dan memiliki karakteristik mudah bergaul, aktif, namun cukup sensitif dalam hal perasaan. Sarah adalah pemeran protagonis yang sedang mencari pria idamannya melalui dating app. Ekspresi Sarah digambarkan sebagai wanita yang periang dan ramah, namun jika ia sedang emosi akan terlihat cukup agresif. Gerakan saat berjalan cukup feminim, saat berbicara terlihat sangat bersemangat sehingga cukup banyak gerakan.

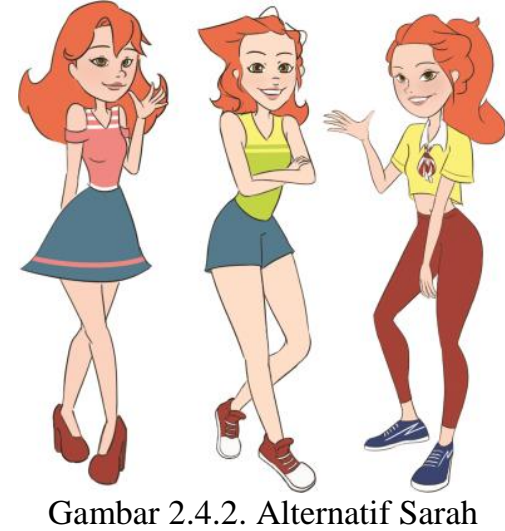

Bill memiliki karakteristik yang berani, percaya diri yang tinggi, aktif, namun tidak peka terhadap sekelilingnya. Bill berperan sebagai antagonis pada cerita ini karena ketidakpekaannya pada Sarah dan terlalu mendominasi dalam pembicaraan. Ekspresi Bill digambarkan dengan tampang flirty dan arrogant. Untuk gerakan saat jalan adalah tegap seperti mencondongkan dada, saat berbicara cukup ekspresif dan banyak gerakan tangan.

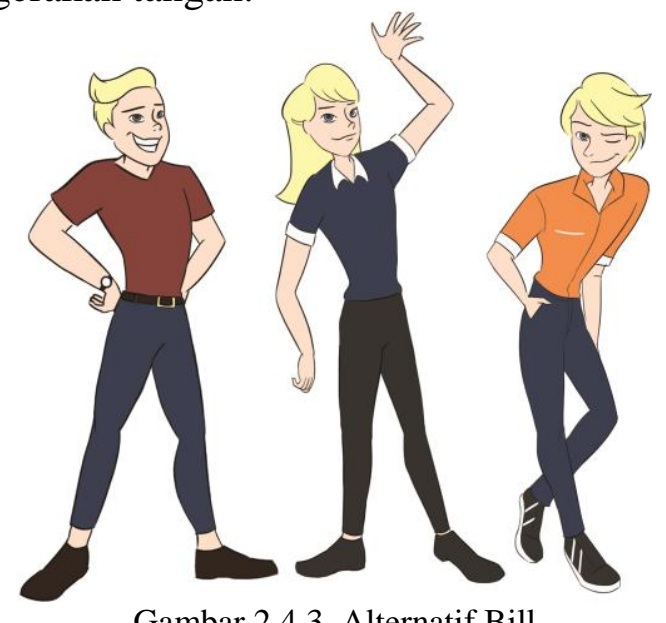

Gambar 2.4.3. Alternatif Bill

\section{Karakter Introvert}

Berbeda dengan ekstrovert, penulis membuat karakter introvert terlihat lebih tenang. Karakter Paul memiliki bentuk tubuh persegi panjang yang menandakan kurus, dan tidak se-energik ekstrovert.

Warna yang digunakan bersifat netral dan redup, rambut coklat, mata hijau, untuk pakaian dengan kombinasi 
warna coklat muda keabuan, coklat tua, hitam, biru gelap, putih dan merah gelap.

Paul adalah seorang yang ramah, dan peka terhadap hal-hal yang ia sukai, namun dibalik wajah yang terlihat kaku dan diam terdapat kegelisahan yang membuat Paul terlihat canggung. Peran Paul adalah sebagai tritagonis, disini ia hadir setelah terjadi konflik antara Sarah dan Bill sebagai penyelamat akhir dari cerita. Paul tidak se-ekspresif Sarah dan Bill, wajah terlihat cuek seperti larut dalam pikiran sendiri, namun ia adalah seorang pendengar yang baik. Saat berjalan postur tubuh paul tegap namun kepala sedikit tertunduk, dan saat berbicara terlihat canggung yang ditutupi dengan senyuman.

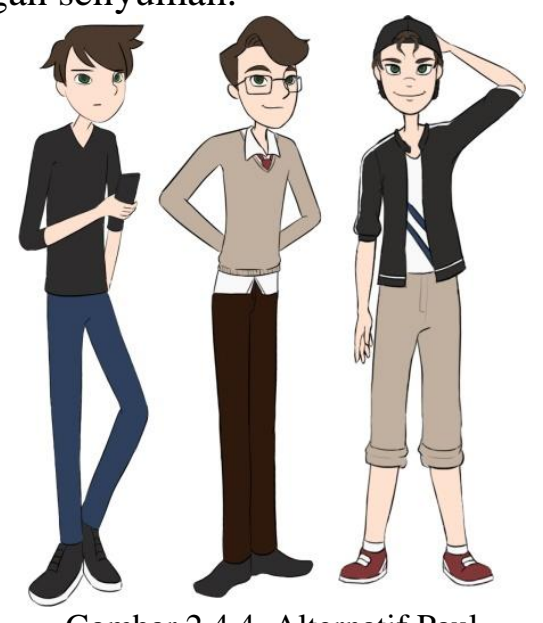

Gambar 2.4.4. Alternatif Paul

\section{Gestur Karakter}

Untuk gesture, berdasarkan observasi dan wawancara yang dilakukan peneliti kepada orang-orang ekstrovert dan introvert, sebagian besar data sesuai dengan apa yang disampaikan Laney mengenai kecenderungan sifat ekstrovert. Seperti point-point (Laney \& Laney, 2007):

1. Mereka berbicara serampangan.

2. Mereka melakukan kontak mata ketika berbicara, sedikit ketika mendengarkan.

3. Ketika berbicara mereka menunjukan ekspresi wajah, menggerakan tubuh muereka, memotong orang lain, berbicara kencang, terdengar otoriter dan silver tongue (mampu secara jelas dan efektif mengekspresikan diri).

Untuk introvert, seperti point-point:

1. Mereka berpikir sebelum bertindak atau berbicara.

2. Mereka melakukan kontak mata ketika mendengarkan, sedikit ketika berbicara.

3. Ketika berbicara mereka memiliki suara lembut, terlihat tenang, sering terhenti, terdengar ragu, dan mencari kata-kata.

\section{Karakter dan Environment}

Terdapat 3 rancangan karakter utama untuk animasi pendek, yaitu:

1. Sarah, seorang wanita ekstrovert yang berumur 25 tahun, Ia berkerja membantu pamannya di sebuah kafe bernama A Cup of Coffee dan tinggal di lantai 3 di kafe tersebut. Sarah adalah seseorang yang aktif, ramah dan banyak pengunjung yang mengenal dan menyukainya. Sifat Sarah mendetail juga akan berdasar tipe kepribadian yang terpilih. Sarah sering bermain dating app di saat-saat cafe nya sepi atau saat bosan, hingga ia bertemu dengan Bill dan Paul.

2. Bill, seorang pria ekstrovert yang berumur 28 tahun. Ia bekerja di perusahaan milik orangtuanya sebagai Direktur. Kelebihan dan Kekurangan Bill akan ditentukan berdasar tipe kepribadian yang terpilih. Namun secara garis besar kelebihan Bill adalah seseorang yang tegas, mempunyai kemauan yang teguh, sangat cocok untuk menjadi seorang direktur. Kekurangan Bill tidak flesksibel atau kaku dan tidak sensitif. Pada awal cerita Bill akan berperan sebagai kekasih Sarah.

3. Paul, seorang pria introvert yang berumur 27 tahun. Ia bekerja pada toko musik atau buku dan menekuni hobi seperti musik, tidak begitu 
ditampilkan dalam cerita. Peran penting Paul adalah setelah Bill dan Sarah mengakhiri hubungan mereka, dicerit dicerita Paul memang sengaja ditakdirkan untuk bertemu dengan Sarah.

Tempat yang akan menjadi latar belakang dari animasi ini negara bernuansa empat musim dan menggunakan style bangunan ala Eropa. Suasana kota tidak terlalu ramai, cukup modern namun masih ada sentuhan vintage. Berikut adalah tempat-tempat yang akan menjadi latar dalam cerita ini.

1. Kafe A Cup of Coffee

2. Jalan sekitar kafe

3. Taman Kota

4. Bioskop

5. Restoran

6. Taman hiburan kecil

7. Mobil

8. Kamar Sarah

9. Balkon atau Rooftop

\section{Perancangan Cerita}

Sarah sedang memainkan dating app, berbagai macam pria tidak menarik hati Sarah sampai sebuah profil menarik muncul di layar hp-nya, Bill. Setelah berkenalan via chat, bertemu, dan menjadi seorang kekasih. Sarah sangat menikmati waktu-waktu indah itu dan berpikir ini adalah waktu terbaik dalam hidup namun lama kelamaan sifat dominasi Bill dan ketidakpekaannya merusak hubungan mereka. Setiap berbicara pun ucapan Sarah selalu diabaikan dan Bill hanya penuh dengan dirinya sendiri. Sarah tidak tahan dengan Bill lalu memutuskan untuk menyudahi hubungannya dengan Bill. Sampai pada suatu waktu, takdir mempertemukan Sarah dan Paul.

\section{SIMPULAN}

Penelitian berperan penting dalam proses menemukan jawaban dari masalah yang dicari yaitu mengetahui karakteristik unik pada ekstrovert dan introvert serta bagaimana merancang hal tersebut menjadi sebuah karakter. Penulis mencari data melalui wawancara kepada ahli, observasi, dan literatur lalu menyimpulkan perbedaan karakteristik ekstrovert dan introvert, yaitu:

1. Ekstrovert memiliki banyak energi yang membuat mereka lebih aktif, sedangkan introvert lebih pendiam.

2. Ekstrovert cenderung lebih terbuka dan mudah bergaul dengan orang lain karena energi yang didapatakan berasal dari luar sedangkan introvert bereaksi secara berbeda, energi terisi seringkali saat sedang kesendirian.

3. Ekstrovert biasanya terlalu banyak bicara membuat mereka terlihat sangat mengganggu, sedangkan introvert terlalu banyak diam membuat mereka terlihat cuek.

4. Ekstrovert biasanya memiliki banyak teman introvert dan juga sebaliknya.

5. Ekstovert biasanya memilih warna yang lebih terang sedangkan introvert ke warna natural atau gelap.

6. Ekstrovert lebih banyak melakukan kontak mata dan gesture tubuh dibanding introvert.

Berdasarkan data-data yang dikumpulkan, maka terbentuklah karakter Sarah, Bill dan Paul. Berdasarkan sifat aktif atau energi maka karakter ekstrovert memiliki badan atletis dan rambut yang lebih mekar dibanding dengan introvert yang dibuat kurus dan lebih kotak. Penggunaan warna-warna terang untuk ekstrovert menunjukan karakter yang terbuka dan periang sedangkan warna natural atau gelap untuk introvert menunjukan karakter yang tenang dan tertutup. Sifat-sifat lainnya akan ditampilkan dalam bentuk gerakan animasinya, seperti penggunaan kontak mata dan gesture lebih sering untuk karakter ekstrovert, gerakan canggung, 
kepala sedikit tertunduk untuk karakter introvert.

Animasi digunakan sebagai salah satu sarana komunikasi untuk menyampaikan informasi secara visual, dan juga sebagai sarana hiburan tidak hanya anak-anak, namun juga dapat dinikmati oleh remaja dan dewasa. Penulis ingin menyampaikan bahwa setiap orang memiliki kepribadian yang berbeda melalui karakter ekstrovert dan introvert, dan tujuan utamanya adalah menunjukan perbedaan sifat antara ekstrovert dengan introvert, serta menunjukan bahwa introvert lebih cocok dengan ekstrovert dibanding dengan kepribadian jenis yang sama melalui animasi yang ber-genre drama dan komedi.

\section{DAFTAR PUSTAKA}

\section{Sumber Buku}

Bancroft, T. (2012). Character Mentor : Learn by Example to Use Expressions, Poses, and Staging to Bring Your Character to Life. Oxford: Taylor \& Francis Ltd.

Beiman, N. (2017). Prepare to Board!: Creating Story and Character for Animated Features and Shorts. Florida: Taylor \& Francis Group.

Bogdan, R.C., \& Biklen, S.K. (1982). Qualitative Research for Education : An Introduction to Theory and Methods. Boston: Allyn and Bacin, Inc.

Feist, G. J., \& Feist, J. (2006). Theories of personality. New York: McGraw Hill

Laney, M.O., \& Laney, M.L. (2007).

The Introvert and Extrovert in Love : Making it Work When Opposites Attract. Oakland: New Harbringer Publications, Inc.
Luscher, M. (1971). The Luscher color test. New York: Pocket Books.

Sugiyono. (2014). Metode Penelitian Pendidikan Pendekatan Kuantitatif, Kualitatif Dan R\&D. Bandung: Alfabeta.

Sullivan, K., Alexander, K., Mintz, A., \& Besen, E. (2013). Ideas for The Animated Short : finding and building stories (2nd ed.). Boston: Focal Press.

Thomas, F., \& Johnston, O. (1981). The Illusion of Life. New York: Abbeville Press.

Tillman, B. (2011). Creativee Character Design. Oxford: Focal Press.

\section{Jurnal/Artikel :}

Bugarski, V., \& Cigic, D. (2010). Personality Traits and Colour Preferences. Current Top Neurological and Psychiatric Relations Discipline, 18(4), 2835.

\section{Sumber Internet}

16Personalities. (2016). Mind: Introverted Vs. Extraverted. Diakses pada Agustus 31, 2017, dari

https://www.16personalities.com/ articles/mind-introverted-vs-

extraverted

Creativebloq. (2015, Juli 27). 20 Top Character Design Tips. Diakses pada Agustus 31, 2017, dari http://www.creativebloq.com/cha racter-design/tips-5132643

Rodrigues, J. G. (Animator). (2016). In/Ex Troversion [Video File]. Diakses dari https://www.youtube.com/watch? $\mathrm{v}=\mathrm{i}-\mathrm{ZPdL} \_\mathrm{MD}-\mathrm{g} \& \mathrm{t}=24 \mathrm{~s}$ 